\title{
Development of a bacterial consortium from Variovorax paradoxus and Pseudomonas veronii isolates applicable in the removal of BTEX
}

Flóra Szentgyörgyi ${ }^{1}$, Tibor Benedek ${ }^{1 *} \oplus$, Dzsenifer Fekete ${ }^{2}$, András Táncsics $^{1}$, Péter Harkai $^{3}$ and Balázs Kriszt ${ }^{3}$

\begin{abstract}
In this study, we report on the development of a novel bacterial consortium, consisting of Variovorax paradoxus and Pseudomonas veronii isolates, applicable in the biodegradation of all six BTEX compounds (benzene, toluene, ethylbenzene, $o^{-}, m$ - and $p$-xylene) and the bioremediation of contaminated sites. The co-cultivability of the selected bacterial isolates was determined in nutrient-rich medium, as well as in BTEX amended mineral salts solution using Terminal Restriction Fragment Length Polymorphism (T-RFLP) and CFU determinations. BTEX biodegradation capacity of the two-strain consortium was assessed in mineral salts solution, where a series of BTEX depletions and supplementations occurred, as well as in a real, BTEX polluted environmental sample (contaminated groundwater) in the presence of the autochthonous bacterial community. The obtained results indicated that the developed bacterial consortium is very efficient in BTEX biodegradation. Under laboratory conditions, the acclimatized bacterial consortium completely degraded the BTEX mixture with a concentration as high as $20 \mathrm{mg} \mathrm{I}^{-1}$ in a mineral salt medium within a short span of $6 \mathrm{~h}$. Close to in situ groundwater conditions (incubated at $15^{\circ} \mathrm{C}$ under static conditions in the absence of light), groundwater microcosms containing the autochthonous bacterial community inoculated with the developed bacterial consortium showed more efficient toluene, $0-, m$-and $p$-xylene biodegradation capacity than microcosms containing solely the native microbial population originally found in the groundwater. In the inoculated microcosms, after $115 \mathrm{~h}$ of incubation the concentration ( $1.7 \mathrm{mg} \mathrm{I}^{-1}$ each) of $\mathrm{o-}, \mathrm{m}$ - and $p$-xylene decreased to zero, whereas in the non-inoculated microcosms the concentration of xylene isomers was still $0.2,0.3$ and $0.3 \mathrm{mg} \mathrm{I}^{-1}$, respectively. The allochthonous bioaugmentation of the contaminated groundwater with the obtained inoculant was successful and manifested in a better BTEX degradation rate. Our results suggest that the obtained bacterial consortium can be a new, stable and efficient bioremediation agent applicable in the synergistic elimination of BTEX compounds from contaminated sites.
\end{abstract}

Keywords: Variovorax, Pseudomonas, Bacterial consortium, Bioaugmentation, BTEX biodegradation

*Correspondence: benedek.tibor@uni-mate.hu

1 Department of Molecular Ecology, Institute of Aquaculture

and Environmental Safety, Hungarian University of Agriculture and Life

Sciences, Gödöllő, Páter K. u. 1, 2100, Hungary

Full list of author information is available at the end of the article

\section{Key points}

- Synergistic BTEX metabolism by a Variovorax and Pseudomonas co-culture

- Complete BTEX biodegradation $\left(20 \mathrm{mg} \mathrm{l}^{-1}\right)$ within only $6 \mathrm{~h}$

- Efficient BTEX biodegradation in the presence of the autochthonous microbial community. 


\section{Introduction}

According to the U.S. EPA, BTEX compounds (benzene, toluene, ethylbenzene, $o-, m$ - and $p$-xylene) are considered as priority pollutants with significant public health concerns. They are included in the list of Hazardous Air Pollutants (rank 78) in the CERCLA List from the 275 substances determined as significant threats to human health (Rahul and Balomajumder, 2013). Benzene and ethylbenzene may induce cancer and neurological effects (Smith et al. 2016). Acute exposure to toluene, $\mathrm{o}^{-}, \mathrm{m}^{-}$ and $p$-xylene may cause neurotoxicity and reproductive dysfunction (Wilbur and Bosch 2004). Despite their detrimental effects on human health, BTEX are one of the most commonly used chemicals in industries such as petroleum, solvent, paint, adhesives, rubber and pesticide (Abumaizar et al. 1998; Atlas and Philp 2005; Fayemiwo et al. 2017). As a matter of fact, the principal sources of BTEX pollution are the aforementioned industries supplemented with coal and biomass burning or the exhaust emissions in urban environments (Kelley et al. 1997; Baltrenas et al. 2011; Mitra and Roy 2011; Datta et al. 2013; Prestes de Castro et al. 2015; Adamović et al. 2018; Zhang et al. 2020).

BTEX pollutions threaten the pedosphere, hydrosphere and the atmosphere (Máthé et al. 2012; Benedek et al. 2016; Farkas et al. 2017). They are one of the most common water resource and potable water contaminants ( $\mathrm{Li}$ et al. 2017). In some African and South-East Asian regions, groundwater contamination with BTEX is particularly worrying since the drinking water used for human consumption is extracted from wells and boreholes fed by the groundwater (Fayemiwo et al. 2017). Recently it has been demonstrated that cigarette butt leachate may be a significant source of pollution of aquatic systems with BTEX compounds (Dobaradaran et al. 2021). In an urban atmosphere BTEX are the most abundant volatile organic compounds (VOCs) (Duan and $\mathrm{Li}$ 2017; Dehghani et al. 2018).

Based on the above, the minimization of BTEX pollutions and at the same time, the restoration of already polluted sites is crucial from a human and environmental health perspective. In recent decades several physicochemical remediation techniques have been developed and applied to remove toxic pollutants from the environment, including BTEX. Such techniques include innovative approaches such as advanced oxidation processes, photocatalysis, sonolysis, radiolysis etc. (Mascolo et al. 2008; Braeutigam et al. 2009; Laokiat et al. 2012; Lee et al. 2013; Al-Sabahi et al. 2017; Dhivakar and Rajan 2018; Mohan et al. 2020). However, although these techniques are effective, they usually have a large ecological footprint and are expensive and impractical on a large scale. Biodegradation and bioremediation of BTEX polluted sites would be the greenest and the cheapest way of problem solving if time is not a constraint (Atlas and Philp 2005). Although it has been used for decades, bioremediation is still a popular technique carrying innovative features (Singh et al. 2017; Lee et al. 2019). Bioaugmentation, a type of bioremediation, is the addition of pregrown bacterial cultures to the polluted sites to reduce clean up time and cost (Mrozik and Piotrowska-Seget 2010). It has to be emphasized, that for the most efficient elimination of xenobiotic compounds from the environment a combination of physico-chemical and biological approaches is the most promising. For instance, bioremediation of soils contaminated with high concentrations of crude oil is usually hampered by high toxicity thresholds for microbial degraders (Vasilyeva et al. 2020). In such cases the initial concentration of toxic pollutants can be decreased using physical and/or chemical methods (e.g., adsorption on granulated activated carbon or diatomite; chemical oxidation) and the residues can be easily removed using biological approaches (Alvarez and Illman 2006; Kulik et al. 2006; Vasilyeva et al. 2020).

The task of researchers in the field of bioremediation should be to search for novel and more efficient microbial capabilities for pollutant elimination. Therefore, in this study, we aimed at obtaining a novel bacterial consortium, made up of a Variovorax (Gammaproteobacteria, Betaproteobacteriales) and a Pseudomonas (Gammaproteobacteria, Pseudomonadales) isolate, applicable in bioaugmentation for rapid and complete bioremediation of BTEX-contaminated sites. To the best of our knowledge, in the literature, there is barely any consortium consisting of Variovorax and Pseudomonas species developed and utilized for the synergistic biodegradation of any kind of organic pollutant. During the study, the BTEX removal capacity of the isolates was tested in the case of single-strains and in co-cultures using either individual compounds or a mixture of BTEX. The co-cultivability and compatibility of strains were tested in nutrient rich media, as well as in mineral salts solution supplemented (spiked) with BTEX as the sole carbon and energy source. The change in the relative abundance of strains during the co-cultivation experiments was determined using cultivation-dependent microbiological and independent molecular biological techniques such as colony-forming unit (CFU) determination and 16S rRNA gene based terminal restriction fragment length polymorphism (T-RFLP) based on community DNA of co-culture samples, respectively. BTEX biodegradation capacity of the consortium was tested on a real BTEX-contaminated groundwater containing the autochthonous microbial community; allochthonous bioaugmentation of the contaminated groundwater was conducted. 


\section{Materials and methods}

\section{Brief characterization of isolates}

Variovorax paradoxus strain BFB1_13 was previously isolated from a bacterial biofilm community selectively enriched on BTEX compounds as the sole source of carbon and energy (50 $\mathrm{mg} \mathrm{l}^{-1}$, the ratio of individual BTEX compounds was 1:1). Enrichments were conducted under aerobic conditions in vitamins and trace elements amended mineral salts solution. When grown on R2A agar plate, strain BFB1_13 forms large, yellowish colonies with a more accentuated yellow color in the middle. Colonies are irregular in shape with raised elevation having high swarming ability (Additional file 1: Fig. S2). As determined previously, isolate BFB1_13 is able to degrade all six BTEX, but mostly benzene, toluene and $o$-xylene, under both aerobic and oxygen-limited conditions (Benedek et al. 2021). Besides I.2.A catechol 2, 3-dioxygenase gene $(\mathrm{C} 23 \mathrm{O})$ involved in aerobic BTEX biodegradation, it also harbors at least four different I.2.C subfamily affiliating $C 230$ genes, possibly playing a role in the oxygen-limited degradation of simple aromatic hydrocarbons (Kukor and Olsen 1996). Based on the whole genome shotgun sequencing of strain BFB1_13, it is a toolbox of catabolic genes involved in simple aromatic hydrocarbon biodegradation (whole genome sequence GenBank accession number JAEVYQ000000000).

Pseudomonas veronii strain BFHA4_7 was isolated from the same biofilm community under similar conditions as strain BFB1_13, but during the enrichment, oxygen-limited conditions were applied; the concentration of $\mathrm{O}_{2}$ was set to $0.5 \mathrm{mg} \mathrm{l}^{-1}$. Strain BFHA4_7 forms large, shiny and smooth, slightly raised, cream-colored colonies with irregular margins when grown on R2A agar (Additional file 1: Fig. S2). As it was determined previously, it is capable of degrading toluene, $m$ - and $p$-xylene. It harbors both I.2.A and I.2.C C23Os involved in aerobic and oxygen-limited degradation of simple aromatic compounds, respectively (Benedek et al. 2018). The $16 S$ rRNA and $\mathrm{C} 23 \mathrm{O}$ gene sequences can be accessed under the accession numbers MG897142, MW922843 (I.2.A C23O) and MG926653 (I.2.C C23O).

Originally, the biofilm serving as a source of isolation of the studied isolates developed in a BTEX-contaminated oxygen-limited groundwater on the surface of a stainlesssteel submersible pump belonging to a Pump and Treat system (P\&T) treating gasoline contaminated groundwater (Benedek et al. 2016 and 2018). Briefly, in 2007 at the contaminated site $\sim 27 \mathrm{~m}^{3}$ of gasoline was leaked accidentally due to the rupture of a refined product pipeline in Central Region of Hungary. 200 tons of soil and the underlying shallow groundwater was contaminated with aliphatic and monoaromatic (BTEX) hydrocarbons. To decontaminate in situ the affected groundwater a physico-chemical P\&T system was established within the contamination plume, treating $30 \mathrm{~m}^{3}$ contaminated groundwater per day. The still in use P\&T system consists of 11 extraction (pumping) and 54 monitoring wells, a central treatment facility, interceptor trenches upgradient and downgradient of the contamination plume, a biofilter, and the associated network of pipes. Massive biofilm formation, the source of isolation of the investigated bacterial strains, occurs on the stainless-steel surface of extraction pumps.

\section{Determination of BTEX biodegradation capacity of strains}

By using either individual or a mixture of compounds, the BTEX biodegradation potential of $V$. paradoxus strain BFB1_13 was thoroughly tested previously under aerobic and oxygen-limited conditions and for planktonic and macro-encapsulated cultures (Benedek et al. 2018, 2021). According to Benedek et al. (2021), V. paradoxus strain BFB1_13 completely degraded the mixture of BTEX (conc. $1.3 \mathrm{mg} \mathrm{l}^{-1}$ each) within $168 \mathrm{~h}$ of incubation under aerobic and oxygen-limited conditions. BTEX degradation by the strain occurred in the following order benzene $>$ toluene $>0$-xylene $>$ ethylbenzene $>m$-, $p$-xylene. On the other hand, as previously determined by Benedek et al. (2018), P. veronii strain BFHA4_7 was capable of degrading only toluene, $m$ - and $p$-xylene as tested in the presence of individual BTEX compounds $\left(5 \mathrm{mg} \mathrm{l}^{-1}\right)$ (Benedek et al. 2018).

\section{Determination of BTEX mixture biodegradation capacity of $P$. veronii BFHA4_7}

As the first step in this study, the BTEX mixture biodegradation capacity of $P$. veronii strain BFHA4_7 was tested by using a mixture of BTEX compounds according to the following:

In $100 \mathrm{ml}$ hermetically closed crimp sealed serum bottles $50 \mathrm{ml}$ of mineral salts solution (composition $\mathrm{CaCl}_{2}$ - $2 \mathrm{H}_{2} \mathrm{O} 0.002$ g; $\mathrm{MgSO}_{4} \cdot 7 \mathrm{H}_{2} \mathrm{O} 0.02$ g; $\mathrm{NH}_{4} \mathrm{NO}_{3} 1$ g; $\mathrm{KH}_{2} \mathrm{PO}_{4} 1 \mathrm{~g} ; \mathrm{K}_{2} \mathrm{HPO}_{4} 1 \mathrm{~g} ; \mathrm{FeCl}_{3} \cdot 6 \mathrm{H}_{2} \mathrm{O} 0.005$ g; $\mathrm{H}_{2} \mathrm{O} 1 \mathrm{l}$, with pH 7) containing $5 \mathrm{mg} \mathrm{l}^{-1}$ of BTEX in total (conc. of each BTEX was $\sim 0.83 \mathrm{mg} \mathrm{l}^{-1}$ ) was inoculated with $70 \mu \mathrm{l}$ of $P$. veronii BFHA4_7 bacterial suspension $\left(\mathrm{OD}_{600 \mathrm{~nm}}=1\right)$ obtained in saline solution $(0.9 \% \mathrm{NaCl})$. According to our preliminary studies, this inoculum volume corresponds to $\sim 5 \cdot 10^{6} P$. veronii BFHA4_7 cells per $\mathrm{ml}$ test solution (data not shown). The obtained microcosms were incubated at $28{ }^{\circ} \mathrm{C}$ while shaking at $145 \mathrm{rpm}$. The goal at this point was to assess whether P. veronii strain BFHA4_7 was capable of degrading all the six BTEX compounds cometabolically (cometabolism-simultaneous degradation of two compounds, in which the degradation of the secondary substrate depends on the presence of the primary substrate; Joshua et al. 2011). The experiments were 
conducted in triplicates in the presence of abiotic control samples.

Testing BTEX biodegradation ability of the co-cultured strains As mentioned earlier, strain BFB1_13 was capable of degrading all six BTEX after only $168 \mathrm{~h}$ of incubation (Benedek et al. 2021). In addition, out of the six BTEX compounds, strain BFHA4_7 degraded only toluene, $m$ and $p$-xylene, cometabolically as well, as this will become apparent in later sections of this study. The goal here was to test whether the two organisms are more efficient together in BTEX biodegradation or not. It was highly expected that there will be catabolic cooperation and the two bacteria complement each other in the BTEX degradation ability leading to faster and more efficient biodegradation of the full range of BTEX.

The tests were conducted in triplicates in $1 \mathrm{~L}$ hermetically closed crimp sealed serum bottles containing $700 \mathrm{ml}$ of the aforementioned mineral salts solution supplemented initially with a mixture of BTEX compounds of $10 \mathrm{mg} \mathrm{l}^{-1}$ in total (conc. $1.7 \mathrm{mg} \mathrm{l}^{-1}$ for each BTEX). Test solutions were co-inoculated with 1-1 ml of each BFB1_13 and BFHA4_7 bacterial suspensions of $\mathrm{OD}_{600 \mathrm{~nm}}=1\left(\sim 10^{6}-10^{6}\right.$ bacterium cells per ml test solution). In the case of complete biodegradation, BTEX supplementations took place. Starting from the second supplementation, $20 \mathrm{mg} \mathrm{l}^{-1}$ of BTEX was added to the microcosms in total (conc. $3.3 \mathrm{mg} \mathrm{l}^{-1}$ for each BTEX). The co-culture microcosm experiment lasted for 8 days with six supplementations in total. Right before the 3rd and 6th BTEX supplementation $60 \mathrm{ml}$ of sterile air was introduced into the bottles to maintain aerobic conditions. $24 \mathrm{~h}$ after the 6 th supplementation the 3rd aeration with injection of $120 \mathrm{ml}$ of sterile air took place.

At the end of the microcosm experiment, the relative abundance of the co-cultured strains was determined by CFU determinations and (ii) $16 S r R N A$ gene-based T-RFLP analysis (for more details please see section Cocultivability of the studied strains in BTEX-amended mineral salts solution).

\section{Testing the biodegradation capacity of the consortium on a real BTEX-contaminated environmental sample}

At this stage of the study, using the two-strain consortium the efficiency of allochthonous bioaugmentation was tested on BTEX biodegradation in a real contaminated groundwater containing the autochthonous microbial community. The microcosm experiments were conducted in triplicates in $1 \mathrm{~L}$ hermetically closed crimp sealed serum bottles containing $700 \mathrm{ml}$ of BTEX-contaminated groundwater originating from the "Siklós"contaminated site of Hungary, well ST/2, sampled on 23rd of March 2021 (the "Siklós"-site was thoroughly described by Táncsics et al. 2012). Groundwater samples were collected according to MSZ ISO 5667-11:2009/1-2 standard and stored in a cooling box and later on at $4{ }^{\circ} \mathrm{C}$. Samples were processed $24 \mathrm{~h}$ after arrival to the laboratory. Original qualitative and quantitative parameters of the contaminated groundwater regarding general water chemistry and hydrocarbon pollutants were determined by an accredited laboratory, the Wessling Hungary Ltd. To determine specific electrical conductivity and groundwater pH MSZ EN ISO 27888:1998 and MSZ ISO 10523:2003 standards were used, respectively. For determination of sulphate and nitrate concentrations MSZ EN ISO 10304-1:2009, for $\mathrm{Fe}^{2+}$ and $\mathrm{Mn}^{2+}$ amounts EPA Method 200.8:1999 and MSZ EN ISO 17294-2:2005 analytical standards were used. To determine the concentration of TPHs (C5-C40) and BTEX, WBSE-26:2009 and MSZ 1484-7: 2009 analytical standards and HP6890-GC FID/PID (Agilent, USA) apparatus were used. Redox potential and temperature values were determined on site by using HI 9829 multiparameter meter (Hanna Instruments). The dissolved oxygen concentration was also determined on site using a HQ30D portable meter (Hach).

At the beginning of the microcosm experiment, to the already contaminated groundwater samples containing the pristine autochthonous microbial community, $10 \mathrm{mg} \mathrm{l}^{-1}$ of extra BTEX mixture was added (spiked) in total (conc. of each BTEX compound was $\sim 1.7 \mathrm{mg} \mathrm{l}^{-1}$ ). Microcosms were co-inoculated with $10-10 \mathrm{ml}$ of each $V$. paradoxus BFB1_13 and P. veronii BFHA4_7 bacterial suspensions of $\mathrm{OD}_{600 \mathrm{~nm}}=0.9$. Inoculants were obtained in mineral salts solution by using $48 \mathrm{~h}$ old cultures developed on R2A plates, revitalized from $-80{ }^{\circ} \mathrm{C}$ stocks. The inoculated groundwater samples contained per $\mathrm{ml} \sim 10^{7}-10^{7}$ BFB1_13 and BFHA4_7 bacterium cells.

Non-inoculated microcosms containing the intact autochthonous microbial community were initiated as well under the same circumstances.

To test if the BTEX biodegradation capacity of the revitalized cells still exists, mineral salts solutions $(50 \mathrm{ml})$ containing $10 \mathrm{mg} \mathrm{l}^{-1}$ BTEX were co-inoculated with 100-100 $\mu \mathrm{l}$ of BFB1_13 and BFHA4_7 bacterial suspensions obtained in the previous step $\left(\mathrm{OD}_{600 \mathrm{~nm}}=0.9\right)$.

To mimic close to in situ conditions, all the microcosms were incubated at $15{ }^{\circ} \mathrm{C}$ under static conditions in the absence of light.

The concentration of BTEX throughout the microcosm experiments was determined from the headspace of the bottles by using an SPME polydimethylsiloxane fiber assembly (Supelco) for sampling. Before GC-MS measurements, $1 \mathrm{~h}$ was left for the BTEX compounds added to the microcosms to reach the equilibrium between the liquid and gas phases (steady-state). Trace 1300 gas 
chromatograph coupled to ISQ Single Quadrupole mass spectrometer (ThermoFisher Scientific, US) was used for analysis. During the measurement, injector and detector temperatures were maintained at $200{ }^{\circ} \mathrm{C}$ and $250{ }^{\circ} \mathrm{C}$, respectively. The oven temperature program was set to $40{ }^{\circ} \mathrm{C}$ for $3 \mathrm{~min}$, then ramped at a rate of $20{ }^{\circ} \mathrm{C} \mathrm{min}-1$ to $190{ }^{\circ} \mathrm{C}$ and finally held for $1 \mathrm{~min}$. Helium was used as carrier gas at a flow rate of $1.2 \mathrm{ml} \mathrm{min}^{-1}$. $\mathrm{SLB}^{\mathrm{TM}}-5 \mathrm{~ms}$ fused silica capillary column was used for separation (30 $\mathrm{m} \times 0.25 \mathrm{~mm} \times 0.25 \mu \mathrm{m}$, Sigma-Aldrich, Supelco). The mass spectrometer was operated at full scan mode.

\section{Testing co-cultivability of the studied bacterial isolates}

Previously, the optimal cultivation conditions for the strains were determined (data not published). According to those results, for the cultivation of both strains modified nutrient-broth (yeast extract $2 \mathrm{~g}$, meat extract $1 \mathrm{~g}$, casein peptone $5 \mathrm{~g}, \mathrm{NaCl} 10 \mathrm{~g}, \mathrm{pH} 7-8, \mathrm{H}_{2} \mathrm{O} 1 \mathrm{~L}$ ) incubated at $28-30{ }^{\circ} \mathrm{C}$ is the most appropriate. Optimization of cultivation conditions showed that compared to P. veronii BFHA4_7 strain V. paradoxus BFB1_13 grows slower in nutrient-broth (Additional file 1: Fig. S3). During co-cultivability tests in nutrient rich medium the difference between the growth rates was taken into consideration.

\section{Determination of strain specific $16 \mathrm{~S}$ rRNA gene-based T-RFLP profiles}

Prior to the co-cultivation experiments, the optimal parameters for the terminal restriction fragment length polymorphism analyses (T-RFLP) were also assessed. T-RFLP is a highly reproducible, quantitative and qualitative molecular method for rapid analysis of microbial communities. Using the $16 S$ rRNA gene-based T-RFLP technique, changes in microbial community structure that occur on temporal or spatial scales can be assessed (Liu et al. 1997). In this study, T-RFLP was used to determine the co-cultivability and temporal dynamics of the studied isolates during the co-cultivation experiments.

To obtain the T-RFLP profiles of the studied strains as a first step, genomic DNA of pure isolates $(24-48 \mathrm{~h}$ old cultures) was extracted by using DNeasy UltraClean Microbial Kit (Qiagen) according to the instructions of the manufacturer. As a second step, 16S rRNA genes were PCR amplified by using Bacteria specific fluorescently labelled 27-VIC-F (5'-AGA GTT TGA TCC TGG CTC AG-3') forward and non-labelled 1492-R (5'-TAC GGY TAC CTT GTT ACG ACT T-3') reverse primers. The conditions of PCR and the used temperature profile were the same as described by Táncsics et al. (2012). Subsequently, $2 \mu \mathrm{l}$ of the obtained fluorescently-labelled $16 S$ rRNA gene amplicons were digested with $3 \mathrm{U}$ of FastDigest RsaI (5'-GT/AC-3') and $1 \mathrm{U}$ of AluI (5'-AG/
CT- $3^{\prime}$ ) restriction endonuclease at $37{ }^{\circ} \mathrm{C}$ for $15 \mathrm{~min}$ and $1.5 \mathrm{~h}$, respectively (ThermoFisher Scientific). The generated fluorescently-labelled terminal restriction fragments (T-RFs) were purified by ethanol precipitation, separated and detected by capillary gel electrophoresis using an ABI 3130 Genetic Analyzer (Applied Biosystems). The applied internal lane size standards were GeneScan ${ }^{\mathrm{TM}} 500$ $\mathrm{LIZ}^{\mathrm{TM}}$ and GeneScan ${ }^{\mathrm{TM}} 1200 \mathrm{LIZ}^{\mathrm{TM}}$ (Applied Biosystems). T-RFLP electropherograms were analyzed with the GeneMapper Software v4.0 (Applied Biosystems).

\section{Co-cultivation of the studied strains in nutrient rich growth medium}

For the co-cultivation of isolates nutrient-broth $(\mathrm{pH}=7$ and $1 \% \mathrm{NaCl}$ ) was used and incubated at $30{ }^{\circ} \mathrm{C}$ and shaken at $160 \mathrm{rpm}$. As a first step, actively growing cultures of P. veronii BFHA4_7 and V. paradoxus BFB1_13 were obtained separately on nutrient-agar for 24 and $48 \mathrm{~h}$, respectively. By using physiological saline solution $(0.9 \% \mathrm{NaCl})$ bacterial suspensions of $\mathrm{OD}_{600 \mathrm{~nm}}=0.5$ were obtained, containing $2.3 \cdot 10^{8}$ and $2.97 \cdot 10^{8}$ cells per ml saline solution for strains BFB1_13 and BFHA4_7, respectively (data obtained earlier, not shown). One liter of nutrient-broth was inoculated first with $100 \mu \mathrm{l}$ of BFB1_13 bacterial suspension, $72 \mathrm{~h}$ later $100 \mu \mathrm{l}$ of BFHA4_7 bacterial suspension was added to the culture. At this step, the faster growth rate of $P$. veronii strain BFHA4_7 was taken into account, as we wanted to avoid over proliferation of strain BFHA4_7 at the expense of strain BFB1_13. After 1 week of incubation, $10 \mathrm{ml}$ of the bacterial suspension was transferred to freshly prepared and sterilized nutrient-broth (1 L) and incubated for one more week. From the one- and two-week-old bacterial cultures, $15-15 \mathrm{ml}$ were centrifuged at $2360 \mathrm{~g}$. The community DNA, originating from the two strains, was extracted from the pellet by using DNeasy UltraClean Microbial Kit (Qiagen) and community T-RFLP analysis was conducted as described above by using RsaI endonuclease. Community T-RFLP profiles for each week were compared and temporal dynamics were assessed.

\section{Co-cultivability of the studied strains in BTEX-amended mineral salts solution}

After 8 days of testing the biodegradation capacity of the co-cultured strains, and after a series of BTEX concentration reductions and supplementations, the relative abundance of the co-cultured strains at the end of the experiment was determined by (i) the enumeration of viable bacterial cells (CFU determinations) and (ii) by $16 S$ rRNA gene-based T-RFLP as described above.

The determination of bacterial cell numbers specific to P. veronii BFHA4_7 and V. paradoxus BFB1_13 was simple since the two strains showed distinct colony 
morphologies (Additional file 1: Fig. S2). After 8 days of incubation, the obtained bacterial suspensions from each replicate were serially diluted up to $10^{8}$. Subsequently, $100 \mu \mathrm{l}$ from each dilution was inoculated onto a nutrient rich medium. The developed strain specific colonies were enumerated after $72 \mathrm{~h}$ of incubation and represented on bar charts.

Before T-RFLP analysis, $50-50 \mathrm{ml}$ of co-cultures were centrifuged at $2360 \mathrm{~g}$ and the community DNA from the two strains was extracted from the pellet by using DNeasy UltraClean Microbial Kit (Qiagen). Fluorescently-labelled T-RFs originating from the two-strain community were generated by using AluI endonuclease and analyzed as described above.

\section{Results}

\section{Results of BTEX biodegradation studies}

BTEX mixture biodegradation capacity of P. veronii BFHA4_7 Similar to the results of individual BTEX biodegradation (Benedek et al. 2018), in the presence of all six BTEX compounds, strain BFHA4_7 was capable of degrading only toluene, $m$ - and $p$-xylene. Complete biodegradation occurred in a relatively short period of time, after $96 \mathrm{~h}$ of incubation (Additional file 1: Fig. S1). In the case of the remaining BTEX, no noticeable biodegradation occurred by the end of the experiment. P. veronii strain BFHA4_7 could not degrade benzene, ethylbenzene and $o$-xylene cometabolically either.

\section{BTEX biodegradation capacity of the two-strain consortium in mineral salts solution}

Within the inoculated samples, after $24 \mathrm{~h}$ of incubation a significant concentration reduction was observed in toluene, $m$ - and $p$-xylene, with the concentration of these compounds decreasing to zero. They were followed by benzene, $o$-xylene and ethylbenzene showing a concentration reduction to $0.5 \pm 0.1,1 \pm 0.1$ and $1.2 \pm 0.1 \mathrm{mg} \mathrm{l}^{-1}$, respectively. After $48 \mathrm{~h}$, all the BTEX were eliminated from the test solutions (total initial conc. $10 \mathrm{mg} \mathrm{l}^{-1}$ ). After the 1st BTEX supplementation, $3 \mathrm{~h}$ were left to reach the equilibrium between the liquid and gas phase (steady-state). After $3 \mathrm{~h}$, notable $p$ - and $m$-xylene concentration reductions occurred (conc. red. to $0.1 \pm 0.1$ and $0.2 \pm 0.1 \mathrm{mg} \mathrm{l}^{-1}$, respectively), followed by toluene (conc. red. to $0.9 \pm 0.2 \mathrm{mg} \mathrm{l}^{-1}$ ) and $o$-xylene (conc. red. to $1.5 \pm 0.2 \mathrm{mg} \mathrm{l}^{-1}$ ). Three hours later, the concentration of all BTEX reduced to zero (in total $6 \mathrm{~h}$ after the 1st supplementation; end of Phase I). Fifteen hours after the 2nd supplementation (total initial conc. of BTEX was $20 \mathrm{mg} \mathrm{l}^{-1}$ ) the concentration reduction of BTEX compounds was at least 99.4\%. Six hours after the 3rd supplementation and I. aeration the concentration of all BTEX reduced to zero. Up until the 104th hour, the degradation of BTEX (20 mg $\left.\mathrm{l}^{-1}\right)$ was complete. However, $10 \mathrm{~h}$ after the 5th supplementation the microcosms showed a slightly reduced BTEX degradation capacity (end of Phase II), but still fourteen hours later the concentration of BTEX reduced to zero again (Fig. 1; Additional file 1: Table S1).

Ten hours after the 6th supplementation and 2nd aeration, complete or near complete elimination was observed in the case of $m$ - and $p$-xylene, as well as toluene. Meanwhile, the concentration of benzene, $o$-xylene and ethylbenzene reduced to $0.9 \pm 0.1,1.4 \pm 0.1 \mathrm{mg} \mathrm{l}^{-1}$ and $1.6 \pm 0.2 \mathrm{mg} \mathrm{l}^{-1}$, respectively. $23 \mathrm{~h}$ later, no remarkable change in benzene, $o$-xylene and ethylbenzene reductions were recorded, notwithstanding a 3rd aeration with $120 \mathrm{ml}$ of sterile air injection was conducted. After $57 \mathrm{~h}$ of the last BTEX supplementation and $33 \mathrm{~h}$ of the 3rd aeration the concentration of BTEX reduced to zero again (end of Phase III; Fig. 1; Additional file 1: Table S1).

\section{Testing the biodegradation capacity of the consortium on a real BTEX-contaminated environmental sample (groundwater)}

As determined prior to the microcosm experiments, the groundwater sample initially contained $0.1,0.8$, and $3.2 \mathrm{mg} \mathrm{l}^{-1}$ of benzene, ethylbenzene and xylenes, respectively. Initially, the concentration of toluene was very low $0.009 \mathrm{mg} \mathrm{l}^{-1}$. Overall, the concentration of total alkyl benzenes was high $7.2 \mathrm{mg} \mathrm{l}^{-1}$.

In the contaminated groundwater, reducing conditions prevailed as indicated by the low dissolved oxygen and redox potential values and high $\mathrm{Fe}(\mathrm{II})$ concentration. The temperature of the groundwater was $13{ }^{\circ} \mathrm{C}$ with a close to neutral $\mathrm{pH}$ (Table 1).

The microcosm experiments spiked with $10 \mathrm{mg} \mathrm{l}^{-1}$ of BTEX were run for 5 days $(115 \mathrm{~h})$ in static cultures incubated at $15{ }^{\circ} \mathrm{C}$ in the dark. As shown in Fig. $2 \mathrm{~A}$ and $\mathrm{C}$, no remarkable difference was observed in the biodegradation of benzene and ethylbenzene between microcosms containing either the autochthonous bacterial community or the autochthonous bacterial community inoculated with $V$. paradoxus BFB1_13 and $P$. veronii BFHA4_7. The rate of biodegradation of these compounds was similar in both settings, after $115 \mathrm{~h}$ of incubation the concentration of benzene and ethylbenzene decreased to zero. In the case of other BTEX compounds, as compared to the autochthonous community, the inoculated microcosms showed a faster biodegradation rate. Throughout the whole experiment, in the case of toluene, $m$ - and $p$-xylene, the inoculated groundwater samples (Autochthonous Community+Inoculum) showed faster biodegradation rates compared to non-inoculated samples. The positive effect of inoculation on $o$-xylene biodegradation manifested only after 


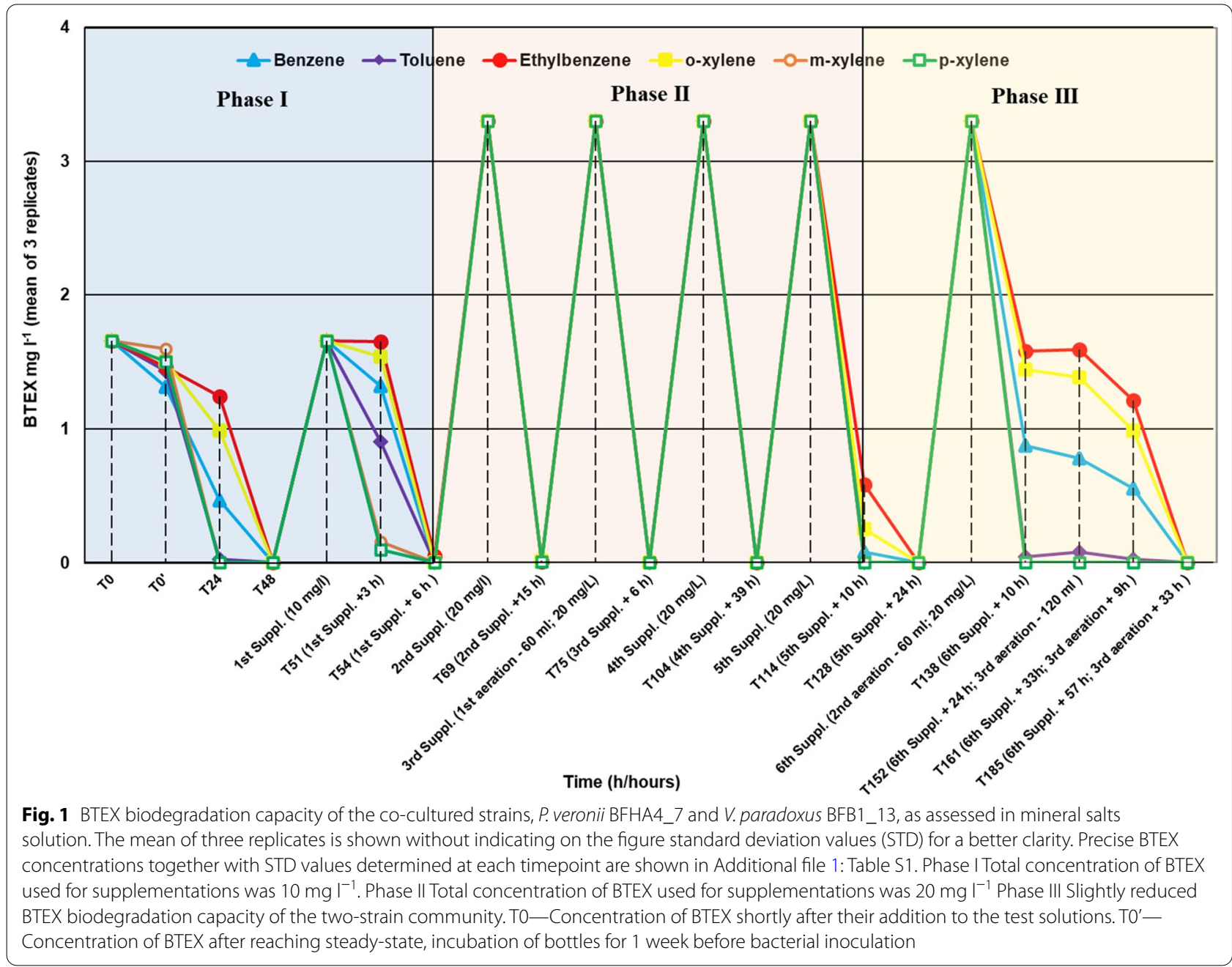

$115 \mathrm{~h}$ of incubation. In the inoculated samples, the concentration of $o$-xylene decreased to zero, whereas in the microcosms containing only the autochthonous bacterial community the remaining $o$-xylene concentration was $0.2 \pm 0.01 \mathrm{mg} \mathrm{l}^{-1}$ (Fig. 2D). During the whole experiment, the most striking difference between inoculated and non-inoculated groundwater microcosms was observed in the case of $m$ - and $p$-xylene, especially $p$-xylene biodegradation (Fig. 2E and F). After $115 \mathrm{~h}$ of incubation, in the inoculated samples the concentration of $m$-xylene decreased to zero. However, a remarkable concentration reduction was recorded already after $25 \mathrm{~h}$ of incubation (Fig. 2E). At the end of the experiment, in the non-inoculated samples the concentration of $m$-xylene was still $0.3 \pm 0.02 \mathrm{mg} \mathrm{l}^{-1}$ (Additional file 1: Table S2).

The fastest biodegradation rate was observed in the case of $p$-xylene. In the inoculated groundwater samples, the concentration of $p$-xylene decreased to zero already after $25 \mathrm{~h}$ of incubation. In the meantime, at the end of the experiment in the non-inoculated microcosms containing only the native microbial community the concentration of $p$-xylene was still $0.3 \pm 0.02 \mu \mathrm{g}{ }^{-1}$ (Fig. 2F).

\section{Results of co-cultivability studies \\ T-RFLP profiles of isolates obtained with Rsal and Alul restriction enzymes}

16S rRNA gene-based T-RFLP profiles of $V$. paradoxus strain BFB1_13 and $P$. veronii strain BFHA4_7 pure cultures were determined. According to the results, using RsaI restriction endonuclease, on the T-RFLP electropherograms a $\sim 420$ bp sized $T-R F$ designates strain BFB1_13 and a T-RF of $\sim 800$ bp indicates strain BFHA4_7 (Additional file 1: Fig. S4 A and B). By using AluI enzyme T-RFs of $\sim 70$ bp and $\sim 148$ bp designate strains BFHA4_7 and BFB1_13, respectively (Additional file 1: Fig. S4C and D).

\section{Co-cultivability of the isolates in nutrient rich medium}

Unexpectedly, the T-RFLP analysis indicated that in a nutrient rich medium, strain BFHA4_7 overproliferated 
Table 1 Results of groundwater chemical analyses at the date of sampling-general water chemistry and the concentration of main petroleum hydrocarbons are shown

\begin{tabular}{|c|c|c|}
\hline $\begin{array}{l}\text { General groundwater chemistry } \\
\text { and pollutants }\end{array}$ & Unit & $\begin{array}{l}\text { Contaminated } \\
\text { well } \\
\text { ST/2 }\end{array}$ \\
\hline Specific electrical conductivity & $\mu \mathrm{S} \mathrm{cm} \mathrm{cm}^{-1}$ & 1360 \\
\hline Redox potential & $m V$ & -19 \\
\hline Dissolved oxygen & $\mathrm{mg} \mathrm{I}^{-1}$ & 0.8 \\
\hline $\mathrm{pH}$ & - & 6.5 \\
\hline Temperature & ${ }^{\circ} \mathrm{C}$ & 13 \\
\hline $\mathrm{SO}_{4}^{2-}$ & $\left.m g\right|^{-1}$ & $<30$ \\
\hline $\mathrm{NO}_{3}^{-}$ & $\left.m g\right|^{-1}$ & $<5$ \\
\hline $\mathrm{Fe}(I I)$ & $\mathrm{mgl}^{-1}$ & 9.4 \\
\hline$M n(I I)$ & $\left.m g\right|^{-1}$ & 4.6 \\
\hline $\mathrm{TPHs}^{\mathrm{a}}$ & $\left.m g\right|^{-1}$ & 1.9 \\
\hline Benzene & $\mathrm{mgl}^{-1}$ & 0.1 \\
\hline Toluene & $\left.m g\right|^{-1}$ & 0.009 \\
\hline Ethylbenzene & $\left.m g\right|^{-1}$ & 0.8 \\
\hline Xylenes & $\left.m g\right|^{-1}$ & 3.2 \\
\hline Other alkyl benzenes & $\left.m g\right|^{-1}$ & 7.2 \\
\hline
\end{tabular}

${ }^{a} \mathrm{TPH}$-Total Aliphatic Petroleum Hydrocarbons $\left(C_{5}-C_{40}\right)$

strain BFB1_13 even though it was inoculated into the medium $72 \mathrm{~h}$ later. After 1 week of incubation, the relative abundance of strain BFHA4_7 affiliated T-RF $(80.7 \pm 3.6 \%)$ was four times higher than that of strain BFB1_13 (19.3 $\pm 3.6 \%)$. After 2 weeks of co-cultivation the strain BFB1_13 related T-RF almost completely disappeared from the nutrient rich co-cultures (Additional file 1: Fig. S5).

\section{Results of co-cultivability of strains in BTEX-amended mineral salts solution}

Compared to co-cultivability tests conducted in nutrient rich medium, quite different results were obtained regarding the co-cultivability of strains in mineral salts solution in the presence of BTEX as a sole source of carbon and energy. After 8 days of incubation in mineral salts solution amended with high concentrations of BTEX, and after a series of BTEX depletions and supplementations, both strains could be re-isolated from the test media in equally high numbers. According to CFU determinations, on average $9 \pm 3.6 \cdot 10^{7}$ and $5.5 \pm 1.7 \cdot$ $10^{7}$ V. paradoxus BFB1_13 and P. veronii BFHA4_7 bacterial cells were present per $\mathrm{ml}$ co-cultures, respectively (Fig. 3).

In contrast to the results obtained in nutrient rich medium, at the end of the experiment the CFU per $\mathrm{ml}$ of $V$. paradoxus strain BFB1_13 was higher than that of $P$. veronii strain BFHA4_7; on average a 1.63-fold difference in CFU was found.
The results of T-RFLP analysis supported the results of CFU determinations. At the end of the experiment, both strains could be detected on the community-based T-RFLP electropherograms. The relative abundance of V. paradoxus BFB1_13 and P. veronii BFHA4_7 affiliated T-RFs were $62.6 \pm 8.3 \%$ and $37.5 \pm 8.3 \%$, respectively. Similar to CFU determinations, a 1.67 -fold difference in the relative abundance between the strains was recorded in favor of strain BFB1_13 (Additional file 1: Fig. S6).

\section{Discussion}

Bioremediation is still the most advantageous approach for the elimination of BTEX pollutions. Within bioremediation, bioaugmentation has an outstanding place, and it has been defined as the inoculation of microorganisms with the capability to degrade the target pollutants in a contaminated environment (Maier 2000; Heinaru et al. 2005). The inoculation can be conducted with one single strain or with a consortium of microbial strains with diverse metabolic capacities. Bioaugmentation has been proposed to be applied in those cases where biostimulation and natural attenuation are ineffective (Iwamoto and Nasu 2001; El Fantroussi and Agathos 2005). Inoculation with microorganisms harboring the necessary metabolic pathways for the degradation of the target pollutants can accelerate the removal rate and, hence, reduce the time and capital required for the remediation (Nowak and Mrozik 2016; Ławniczak et al. 2020). However, the success of microbial cell bioaugmentation highly depends on the survival rate and maintenance of catabolic activity of the microbial strains introduced into the contaminated environment (Singh and Ward 2004). The inoculated strains must compete with the autochthonous microbial populations already present at the contaminated sites regarding the usage of sources of energy, nutrients and electron acceptors (Ławniczak et al. 2020). Furthermore, the inoculated strains must stand the harsh abiotic conditions dominating the contaminated environment too. Both biotic and abiotic factors may lead to high mortality of the inoculated microorganisms, introduced bacteria may become undetectable soon after inoculation (Garbisu et al. 2017).

In this study, a novel bacterial consortium made up of strains V. paradoxus BFB1_13 and P. veronii BFHA4_7 was developed for rapid and complete biodegradation of BTEX compounds. It must be emphasized that although bacterial consortia for BTEX removal do exist in general, these inoculants were tested mostly either under laboratory conditions (room temperature or above, shaking cultures, absence of autochthonous community) or without studying biodegradation of all three xylene isomers separately (Attaway and Schmidt 2002; Shim et al. 2002; Deeb and Alvarez-Cohen 1999; 


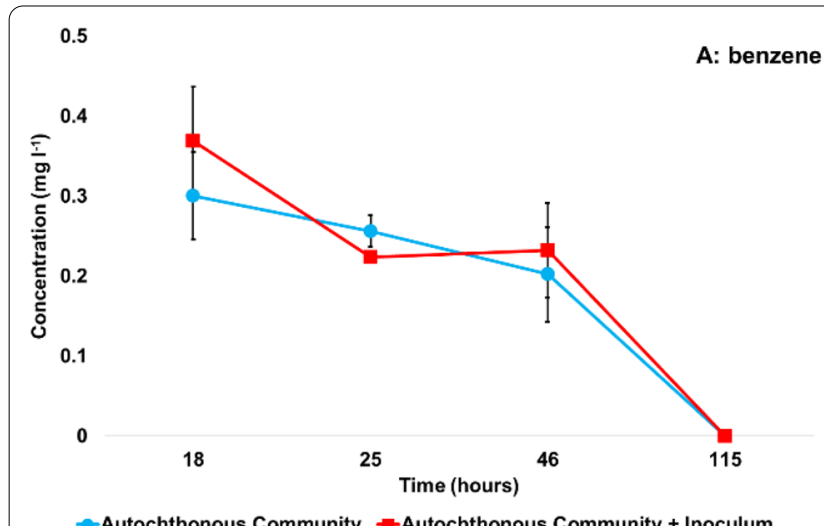

0.4

B: toluene

-Autochthonous Community - Autochthonous Community + Inoculum

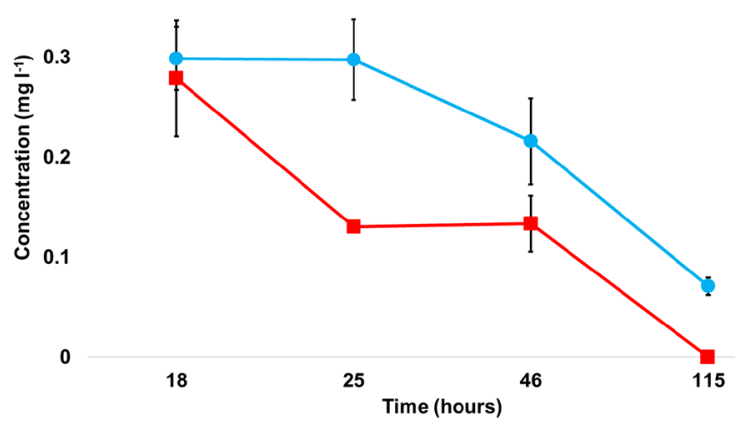

- Autochthonous Community - -Autochthonous Community + Inoculum

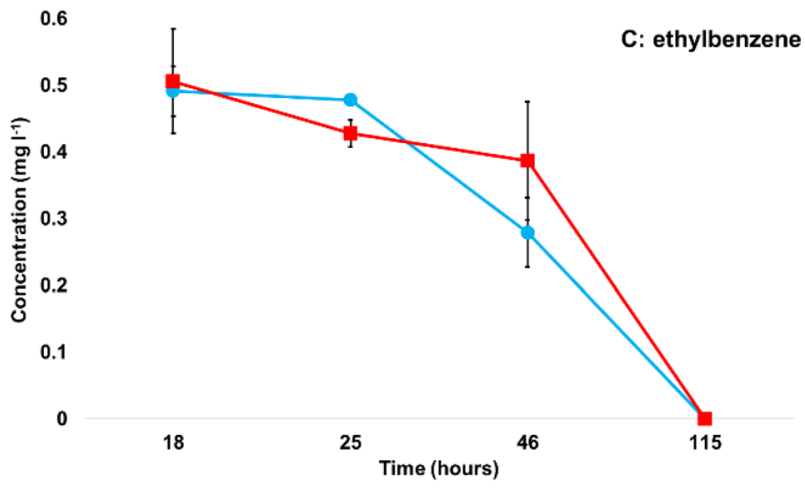

0.5

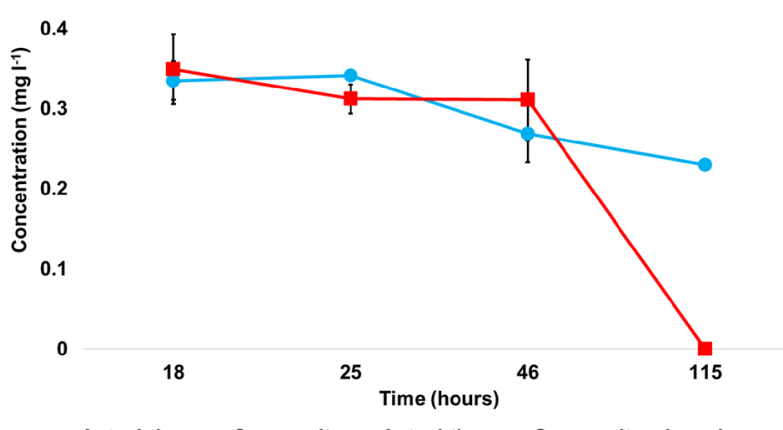

- Autochthonous Community - -Autochthonous Community + Inoculum

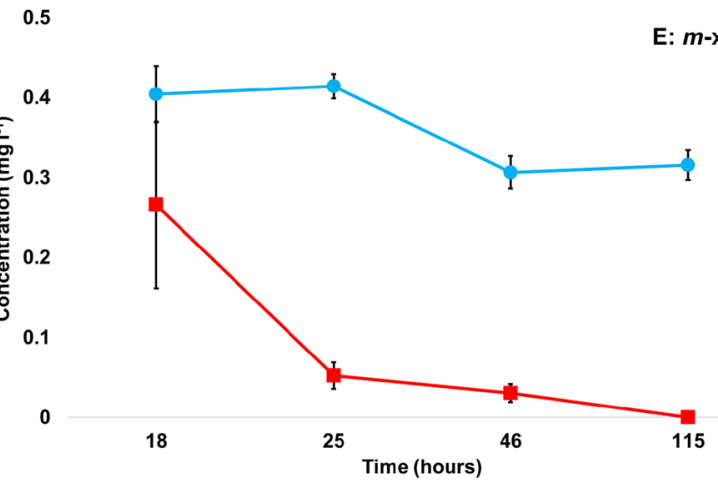

0.6

F: p-xylene

-Autochthonous Community -Autochthonous Community + Inoculum

Fig. 2 BTEX biodegradation capacity of microcosms containing solely the autochthonous bacterial community (blue lines, circle) and the autochthonous bacterial community inoculated with V. paradoxus BFB1_13 and P. veronii BFHA4_7 strains (Inoculum; red lines, square). The time frame between the 18th and 115th hours of incubation is shown. At each time point mean BTEX concentrations together with standard deviation values represented as error bars are depicted. When error bars are not visible, they are hidden behind the symbols (Additional file 1: Table S2). A Benzene; B Toluene; C Ethylbenzene; D o-xylene; E m-xylene; F p-xylene

Arafa 2003; Farhadian et al. 2008; Mazzeo et al. 2010; Fellie et al. 2012; El-Naas et al. 2014; Nagarajan and Loh 2015). For the sake of completeness, it should be pointed out that the applied total BTEX concentration in this study (10-20 $\left.\mathrm{mg} \mathrm{l}^{-1}\right)$ was below the applied concentrations in previous studies mentioned above (50$600 \mathrm{mg} \mathrm{l}^{-1}$ ), however from an environmental pollution point of view it was still in the range of high BTEX 


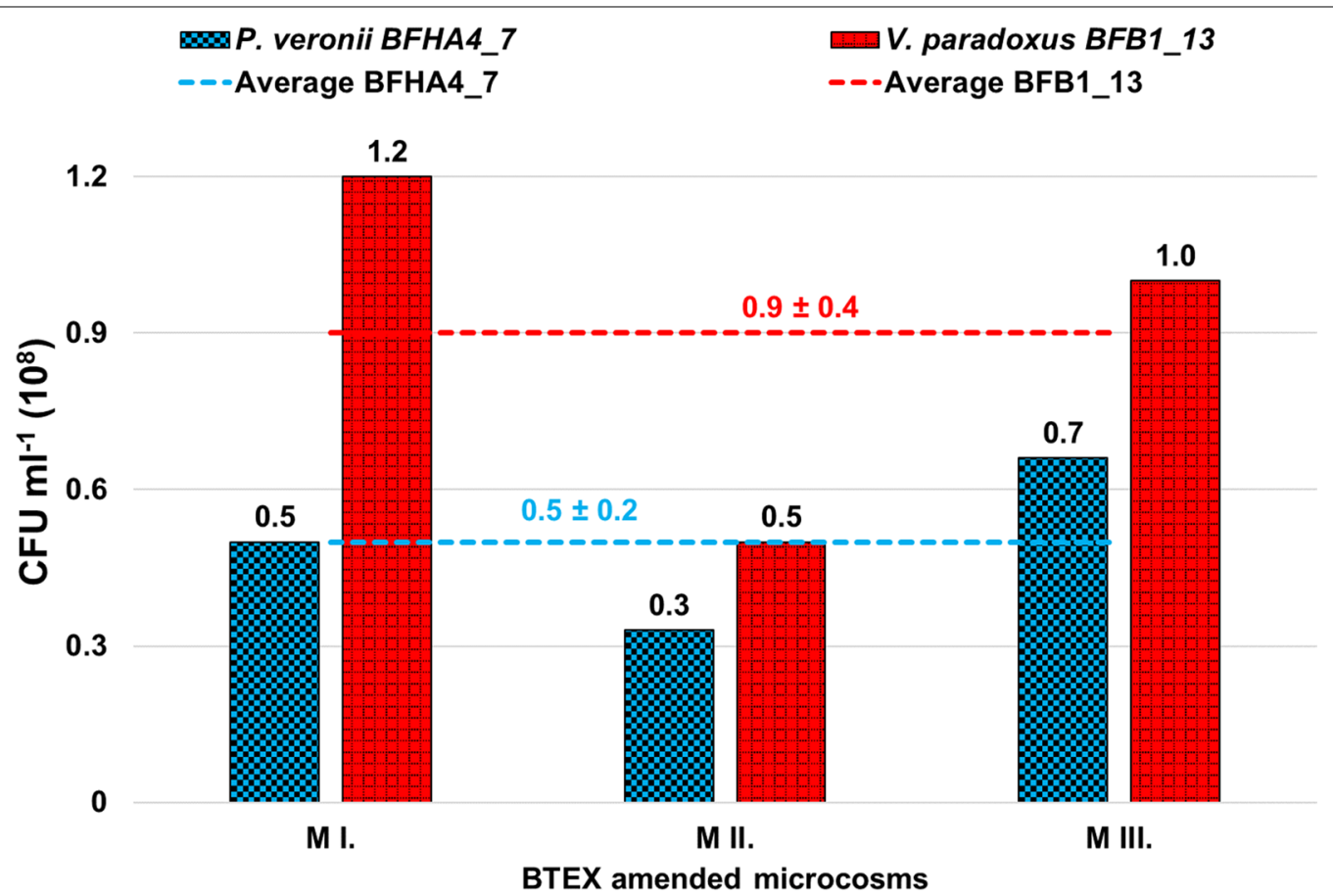

Fig. 3 Results of colony forming unit (CFU) determination of P. veronii BFHA4_7 and V. paradoxus BFB1_13 strains re-isolated from the BTEX amended (total conc. 10-20 $\mathrm{mg} \mathrm{I}^{-1}$ ) mineral salts solution microcosms (M; I. II. and III. replicates). Re-isolations took place after 8 days of incubation

contamination. Bacterial consortia containing species such as Variovorax sp. and Pseudomonas sp. do exist and are used for the degradation of e.g., linuron and 2,4-dinitrotoluene (Dejonghe et al. 2003; Snellinx et al. 2003). According to Satola et al. (2013) V. paradoxus affiliated isolates are capable of degrading a wide variety of recalcitrant organic pollutants such as PAHs, PCBs, dinitrotoluene, and trichloroethylene. Until recently (Benedek et al. 2021), there was no information regarding the BTEX biodegradation capacity of $V$. paradoxus pure cultures, although members of the genus Variovorax are often detected at petroleum hydrocarbon contaminated sites where the primary contaminants are simple aromatic hydrocarbons such as BTEX (Hendrickx et al. 2006; Benedek et al. 2016 and 2018; Posman et al. 2017). On the other hand, based on studies dealing with the metabolism and genetics of bacteria degrading simple aromatic hydrocarbons, it is evident that Pseudomonas species are highly involved in the degradation of BTEX (Arenghi et al. 2001; Hendrickx et al. 2005; Wang et al. 2008). Moreover, based on the literature, isolates affiliating with $P$. veronii, besides BTEX compounds, are able to use as a sole source of carbon and energy different hydrocarbons, including phenolic compounds, alkyl methyl ketones, chlorinated aromatic hydrocarbons and dioxins (Ajithkumar et al
2003; Nam et al. 2003; Hong et al. 2004; Onaca et al. 2007; Morales et al. 2016).

Based on the above mentioned, it is reasonable to develop such a bacterial consortium that according to the obtained results is very effective in BTEX biodegradation under laboratory conditions and close to in-situ conditions as well in the presence of the autochthonous microbial community of BTEX-contaminated groundwater. Although in nutrient rich medium $P$. veronii strain BFHA4_7 overproliferated V. paradoxus strain BFB1_13, in BTEX amended mineral salts solution the proportions in relative abundance changed in favor of strain BFB1_13. From Fig. 1. it is evident that the biodegradation of BTEX by the consortium is initiated by $P$. veronii BFHA4_7. First BTEX compounds whose concentration decreased to zero were $p$-, $m$-xylene and toluene, mainly specific to strain BFHA4_7 (Phase I and III). The degradation of BTEX compounds specific to strain BFB1_13 (benzene, ethylbenzene and $o$-xylene) also occurred but was slightly delayed. The synergistic degradation of BTEX by the obtained consortium is supported on the one hand by these findings and also by the fact that all the six BTEX compounds were completely degraded from the bottles and at the end of the microcosm experiment both strains could be re-isolated in high number $\left(10^{8} \mathrm{CFU} \mathrm{ml} \mathrm{m}^{-1}\right)$. In the co-inoculated mineral salts solution, BTEX 
biodegradation occurred in as little as $6 \mathrm{~h}$. However, it has to be mentioned that rapid BTEX biodegradation was observable until the 104th hours of incubation after which a reduction in BTEX biodegradation capacity of the consortium occurred (Fig. 1). Decreased biodegradation ability of the strains can be explained with the intervening of a weekend when no BTEX supplementation took place for $40 \mathrm{~h}$, from Saturday afternoon until Monday morning. Presumably, the BTEX supplemented on Saturday afternoon were quickly degraded and for the rest of the weekend the culture left without carbon and energy source, and entered the stationary phase. However, according to Phase III (Fig. 1) the BTEX biodegradation capacity of the two-strain community revived and $57 \mathrm{~h}$ after the last BTEX supplementation the concentration of BTEX reduced again to zero. Accordingly, the consortium has the ability to quickly reactivate its BTEX biodegradation capacity after a carbon source starvation period. All the above-mentioned results and the fact that V. paradoxus BFB1_13 did not disappear from the BTEX supplemented test solutions and exceeded in cell number $P$. veronii strain BFHA4_7 by the end of the experiment, may indicate that the two strains complement their metabolic capacities in BTEX biodegradation and work in synergy to gain energy from the breakdown of BTEX compounds specific to them.

Most importantly, under close to in situ conditions the consortium proved to be effective in BTEX biodegradation in a real BTEX-contaminated groundwater too, containing the autochthonous microbial community (total conc. of applied BTEX was $\sim 10 \mathrm{mg} \mathrm{l}^{-1}$ ). The allochthonous bioaugmentation with the engineered consortium proved successful. The "Siklós"-contaminated site existed for more than twenty years and the autochthonous community had enough time to adapt to the contaminants, according to the results of analytical chemistry the concentration of alkyl-benzenes, including BTEX except for toluene, is still high in the groundwater (Table 1). Based on Fig. 2, the inoculation with the two-strain consortium positively impacted the BTEX biodegradation process, taking place in the groundwater samples. Regarding benzene, toluene and ethylbenzene no remarkable beneficial effect of the inoculation was found compared to the activity of the autochthonous community. In the case of xylenes' biodegradation, the positive effect of the inoculation was pronounced. These results indicate that most probably the autochthonous microbial community in the groundwater inherently harbors benzene, toluene and ethylbenzene biodegradation capacity, but the xylenes elimination potential of the community is low. In the inoculated groundwater samples complete or near complete $p$ - and $m$-xylenes biodegradation occurred within $25 \mathrm{~h}$ of incubation (BTEX compounds specific to $P$. veronii BFHA4_7), whereas in the microcosms containing solely the autochthonous community, the concentration of these compounds was still $0.4 \mathrm{mg} \mathrm{l}^{-1}\left(400 \mu \mathrm{g} \mathrm{l}^{-1}\right)$. After $115 \mathrm{~h}$ of incubation, complete $o$-xylene biodegradation occurred (specific to $V$. paradoxus BFB1_13) only in the case of inoculated groundwater microcosms. At this point, $o$-xylene concentration in the non-inoculated groundwater microcosms was $0.23 \mathrm{mg} \mathrm{l}^{-1}\left(230 \mu \mathrm{g} \mathrm{l}^{-1}\right)$. Even after 2 weeks of incubation, in the non-inoculated groundwater samples the concentration of $\mathrm{o}_{-}, \mathrm{m}_{-}$, and $p$-xylene was 128.9, 73.7 and $52.2 \mu \mathrm{g} \mathrm{l}^{-1}$, respectively. Based on the aforementioned results, it can be assumed that the biodegradation of xylenes by the autochthonous bacterial community found in the groundwater occurs cometabolically. As long as there are other BTEX compounds in the environment the biodegradation of xylenes is efficient. As soon as benzene, toluene and ethylbenzene are being depleted, the biodegradation of xylenes ceases. Cometabolic xylene biodegradation has been demonstrated earlier. According to Littlejohns and Daugulis (2008) $o$-xylene was the most resistant against biodegradation by a bacterial consortium containing seven Pseudomonas species. The obtained results indicated that $o$-xylene, unlike benzene, toluene and ethylbenzene, was not metabolized by the consortium when being the only carbon source present. It was cometabolized only in the presence of both benzene and toluene. In the presence of ethylbenzene as co-substrate $o$-xylene was not metabolized. In addition, Chang et al. (1993) isolated a Pseudomonas sp. strain B1 able to grow on benzene and toluene as the sole sources of carbon and energy. The strain was capable of $p$-xylene biodegradation only cometabolically in the presence of toluene. Results of Miri et al. (2021) also pointed out that $p$-xylene biodegradation by $P$. putida was enhanced in the presence of either toluene or benzene; toluene assimilating cells degraded $p$-xylene more effectively than other substrates.

In summary, it can be concluded that a novel BTEX biodegrading bacterial inoculant was developed applicable under close to in situ conditions, in the presence of the autochthonous microbial community found in a BTEX-contaminated groundwater sample. To the best of our knowledge, such a study, which includes testing the inoculant under close to in situ conditions in the presence of the autochthonous microbial community, for the development of a BTEX-degrading bacterial consortium has not been reported earlier. The obtained two-strain consortium in co-cultures performs better in BTEX biodegradation than in single cultures. Biodegradation of the full range of BTEX occurred faster in co-cultures, and the catabolic cooperation between the two strains was demonstrated. The most significant advantage of this consortium is that, unlike most of other bacterial consortia 
found in the literature, the role of each member in BTEX biodegradation is clearly defined and the efficiency of the inoculum was also tested on a real BTEX-contaminated groundwater through allochthonous bioaugmentation.

Regarding future perspectives, it would be worth determining the BTEX biodegradation capacity of the obtained bacterial consortium under oxygen-limited conditions ( $\leq 2 \mathrm{mg} \mathrm{l}^{-1}, \mathrm{O}_{2}$ concentration prevailing at hydrocarbon contaminated sites), again in the presence of the autochthonous microbial community already existing in the contaminated groundwater. It is highly assumed that the consortium will be efficient in BTEX biodegradation also under oxygen-limited conditions since both strains harbor I.2.C C23Os involved in oxygen-limited aromatic hydrocarbon biodegradation. Additionally, a long-term microcosm experiment should also be carried out in the presence of the autochthonous community, by conducting a series of BTEX depletions and supplementations, to assess the long-term survival of the inoculant in the presence of the native microbial community.

\section{Supplementary Information}

The online version contains supplementary material available at https://doi. org/10.1186/s13568-022-01349-2.

Additional file 1. Supplementary information regarding the colony morphology, T-RFLP profile of the studies isolates, and supplemetary data regarding BTEX-biodegradation capacity of the consortium

\section{Acknowledgements}

The authors are thankful for Dr. Jeffrey Griffitts (Hungarian University of Agriculture and Life Sciences) for proofreading and editing tips.

\section{Authors' contributions}

TB, AT and BK conceived and designed the study. TB and FSZ wrote the paper. FSZ and DF conducted experiments. PH sampled the BTEX-contaminated groundwater and provided information regarding physico-chemical properties of the samples.

\section{Funding}

Open access funding provided by Hungarian University of Agriculture and Life Sciences. This research work was supported by the Ministry of Innovation and Technology within the framework of the Thematic Excellence Programme 2020, Institutional Excellence Subprogramme (TKP2020-IKA-12). T. B. was supported by the National Research, Development and Innovation Office-PD 128831. A. T. acknowledges the support of the "OTKA"Young Researcher Excellence Programme (FK 134439)

\section{Availability of data and materials}

Data generated or analyzed during this study are included in this published article (and its supplementary information files). V. paradoxus BFB1_13 and P. veronii BFHA4_7 are deposited in the National Collection of Agricultural and Industrial Microorganisms (NCAIM, Budapest, Hungary) under the accession numbers NCAIM B.02666 and NCAIM B. 02670, respectively.

\section{Declarations}

Ethics approval and consent to participate

This article does not contain any studies with human participants or animals performed by any of the authors.

\section{Consent for publication}

Not applicable.

\section{Competing interests}

The authors declare that they have no conflict of interests.

\section{Author details}

${ }^{1}$ Department of Molecular Ecology, Institute of Aquaculture and Environmental Safety, Hungarian University of Agriculture and Life Sciences, Gödöllő, Páter K. u. 1, 2100, Hungary. ${ }^{2}$ Soós Ernő Research and Development Center, Circular Economy University Center, University of Pannonia, Nagykanizsa, Zrínyi u. 18, 8800, Hungary. ${ }^{3}$ Department of Environmental Safety, Institute of Aquaculture and Environmental Safety, Hungarian University of Agriculture and Life Sciences, Gödöllő, Páter K. u. 1, 2100, Hungary.

Received: 11 January 2022 Accepted: 16 January 2022

Published online: 25 January 2022

\section{References}

Abumaizar RJ, Kocher W, Smith EH (1998) Biofiltration of BTEX contaminated air streams using compost-activated carbon filter media. J Hazard Mater 60:111-126

Adamović D, Dorić J, Vojinović Miloradov M, Adamović S, Pap S, Radonić J, Turk Sekulić M (2018) The emission of BTEX compounds during movement of passenger car in accordance with the NEDC. Sci Tot Environ 639:339-349

Ajithkumar B, Ajithkumar VP, Iriye R (2003) Degradation of 4-amylphenol and 4-hexylphenol by a new activated sludge isolate of Pseudomonas veronii and proposal for a new subspecies status. Res Microbiol 154:17-23

Al-Sabahi J, Bora T, Al-Abri M, Dutta J (2017) Efficient visible light photocatalysis of benzene, toluene, ethylbenzene and xylene (BTEX) in aqueous solutions using supported zinc oxide nanorods. PLoS ONE. https://doi. org/10.1371/journal.pone.0189276

Alvarez PJJ, IIIman WA (2006) In: Schnoor JL, Zehnder A Eds. Bioremediation and natural attenuation Process fundamentals and mathematical models. New Jersey: Willey-InterScience, 612

Arafa MA (2003) Biodegradation of some aromatic hydrocarbons (BTEXs) by a bacterial consortium isolated from polluted site in Saudi Arabia. Pak J Biol Sci 6:1482-1486

Arenghi FL, Berlanda D, Galli E, Sello G, Barbieri P (2001) Organization and regulation of meta cleavage pathway genes for toluene and o-xylene derivative degradation in Pseudomonas stutzeri OX1. Appl Environ Microbiol 67:3304-3308

Atlas RM, Philp J (2005) Bioremediation: applied microbial solutions for realworld environmental cleanup. Edited by Atlas RM and Philp J, ASM Press, Washington D.C.

Attaway HH, Schmidt MG (2002) Tandem biodegradation of BTEX components by two Pseudomonas sp. Curr Microbiol 45:30-36

Baltrenas P, Baltrenaite E, Sereviciene V, Pereira P (2011) Atmospheric BTEX concentration in the vicinity of the crude oil refinery of the Baltic region. Environ Monit Assess 182:115-127

Benedek T, Táncsics A, Szabó I, Farkas M, Szoboszlay S, Fábián K, Maróti G, Kriszt B (2016) Polyphasic analysis of an Azoarcus-Leptothrix-dominated bacterial biofilm developed on stainless steel surface in a gasoline-contaminated hypoxic groundwater. Environ Sci Pollut Res 23:9019-9035

Benedek T, Sz F, Szabó I, Kriszt B, Révész F, Radó J, Maróti G, Táncsics A (2018) Aerobic and oxygen-limited enrichment of BTEX-degrading biofilm bacteria: dominance of Malikia versus Acidovorax species. Environ Sci Pollut Res 25:32178-32195

BenedekT, Szentgyörgyi F, Gergócs V, Menashe O, Figueroa Gonzalez PA, Probst AJ, Kriszt B, Táncsics A (2021) Potential of Variovorax paradoxus isolate BFB1_13 for bioremediation of BTEX contaminated sites. AMB Express. https://doi.org/10.1186/s13568-021-01289-3

Braeutigam P, Wu ZL, Stark A, Ondruschka B (2009) Degradation of BTEX in aqueous solution by hydrodynamic cavitation. Chem Eng Technol 32:745-753

Chang MK, Voice TC, Criddle CS (1993) Kinetics of competitive inhibition and cometabolism in the biodegradation of benzene, toluene, and p-xylene by two Pseudomonas isolates. Biotechnol Bioeng 41:1057-1065 
Datta A, Philip L, Bhallamudi SM (2013) Modeling the biodegradation kinetics of aromatic and aliphatic volatile pollutant mixture in liquid phase. Chem Eng J 241:288-300

Deeb RA, Alvarez-Cohen L (1999) Temperature and substrate interactions during the aerobic biotransformation of BTEX mixtures by toluene-enriched consortia and Rhodococcus rhodochrous. Biotechnol Bioeng 62:526-536

Dehghani M, Fazlzadeh M, Sorooshian A, Tabatabaee HR, Miri M, Baghani AN, Delikhoon M, Mahvi AH, Rashidi M (2018) Characteristics and health effects of BTEX in a hot spot for urban pollution. Ecotoxicol Environ Saf 155:133-143

Dejonghe W, Berteloot E, Goris J, Boon N, Crul K, Maertens S, Höfte M, De Vos P, Verstraete W, Top EM (2003) Synergistic degradation of linuron by a bacterial consortium and isolation of a single linuron-degrading Variovorax strain. Appl Environ Microbiol 69:1532-1541

Dhivakar V, Rajan T (2018) BTEX compounds removal from waste water by using UV\&UV/ $\mathrm{H}_{2} \mathrm{O}_{2}$ Process. Int J Recent Eng Sci 5:22-25

Dobaradaran S, Schmidt TC, Kaziur-Cegla W, Jochmann MA (2021) BTEX compounds leachates from cigarette butts into water environment: a primary study. Environ Pollut. https://doi.org/10.1016/j.envpol.2020.116185

Duan X, LiY (2017) Sources and fates of BTEX in the general environment and its distribution in coastal cities of China. J Environ Sci Public Health 1:86-106

El-Naas MH, Acio JA, El Telib AE (2014) Aerobic biodegradation of BTEX: progress and prospects. J Environ Chem Eng 2:1104-1122

El Fantroussi S, Agathos SN (2005) Is bioaugmentation a feasible strategy for pollutant removal and site remediation? Curr Opin Microbiol 8:268-275

Farhadian M, Vachelard C, Duchez D, Larroche C (2008) In situ bioremediation of monoaromatic pollutants in groundwater: a review. Biores Technol 99:5296-5308

Farkas M, Szoboszlay S, Benedek T, Révész F, Veres PG, Kriszt B, Táncsics A (2017) Enrichment of dissimilatory Fe(III)-reducing bacteria from groundwater of the Siklós BTEX contaminated site (Hungary). Folia Microbiol 62:63-71

Fayemiwo OM, Daramola MO, Moothi K (2017) BTEX compounds in waterfuture trends and directions for water treatment. Water SA 43:602-613

Fellie EA, Sannasi P, Wong KK, Salmijah S, Kader J (2012) Tolerance and biodegradation of benzene, toluene, ethylbenzene and xylenes (BTEX) by a metal acclimatized bacterial consortium culture. Res J Biotechnol 7:52-58

Garbisu C, Garaiyurrebaso O, Epelde L, Grohmann E, Alkorta I (2017) Plasmidmediated bioaugmentation for the bioremediation of contaminated soils. Front Microbiol. https://doi.org/10.3389/fmicb.2017.01966

Heinaru E, Merimaa M, Viggor S, Lehiste M, Leito I, Truu J, Heinaru A (2005) Biodegradation efficiency of functionally important populations selected for bioaugmentation in phenol and oil-polluted area. FEMS Microbiol Ecol 51:363-373

Hendrickx B, Dejonghe W, Boenne W, Brennerova M, Cernik M, Lederer T, Bucheli-Witschel M, Bastiaens L, Verstraete W, Top EM, Diels L, Springael D (2005) Dynamics of an oligotrophic bacterial aquifer community during contact with a groundwater plume contaminated with benzene, toluene, ethylbenzene, and xylenes: an in situ mesocosm study. Appl Environ Microbiol 71:3815-3825

Hendrickx B, Junca H, Vosahlova J, Lindner A, Rüegg I, Bucheli-Witschel M, Faber F, Egli T, Mau M, Schlömann M, Brennerova M, Brenner V, Pieper DH, Top EM, Dejonghe W, Bastiaens L, Springael D (2006) Alternative primer sets for PCR detection of genotypes involved in bacterial aerobic BTEX degradation: distribution of the genes in BTEX-degrading isolates and in subsurface soils of a BTEX contaminated industrial site. J Microbiol Methods 64:250-265

Hong HB, Nam IH, Murugsen K, Kim YM, Chang YS (2004) Biodegradation of dibenzo-p-dioxin, dibenzofuran, and chlorodibenzo-p-dioxins. Biodegr 15:3030-3313

Iwamoto T, Nasu M (2001) Current bioremediation practice and perspective. J Biosci Bioeng 92:1-8

Joshua CJ, Dahl R, Benke PI, Keasling JD (2011) Absence of diauxie during simultaneous utilization of glucose and xylose by Sulfolobus acidocaldarius. J Bacteriol 193:1293-1301

Kelley CA, Hammer BT, Coffin RB (1997) Concentrations and Stable Isotope values of BTEX in gasoline-contaminated groundwater. Environ Sci Technol $31: 2469-2472$

Kukor JJ, Olsen RH (1996) Catechol 2,3-dioxygenases functional in oxygenlimited (hypoxic) environments. Appl Env Microbiol 62:1728-1740
Kulik N, Goi A, Trapido M, Tuhkanen T (2006) Degradation of polycyclic aromatic hydrocarbons by combined chemical pre-oxidation and bioremediation in creosote contaminated soil. J Environ Manage 78:382-391

Laokiat L, Khemthong P, Grisdanurak N, Sreearunothai P, Pattanasiriwisawa W, Klysubun W (2012) Photocatalytic degradation of benzene, toluene, ethylbenzene, and xylenes (BTEX) using transition metal-doped titanium dioxide immobilized on fiberglass cloth. Korean J Chem Eng 29:377-383

Ławniczak L, Woźniak-Karczewska M, Loibner AP, Heipieper HJ, Chrzanowski $L$ (2020) Microbial degradation of hydrocarbons-basic principles for bioremediation: a review. Molecules 25:856

Lee JH, Park JJ, Choi GC, Byun I, Park TJ, Lee TH (2013) Application of ultrasound and air stripping for the removal of aromatic hydrocarbons from spent sulfidic caustic for use in autotrophic denitrification as an electron donor. Water Sci Technol 67:1497-1502

Lee Y, Lee Y, Jeon CO (2019) Biodegradation of naphthalene, BTEX, and aliphatic hydrocarbons by Paraburkholderia aromaticivorans BN5 isolated from petroleum-contaminated soil. Sci Rep 9:860

Li J, Alves de Toledo R, Shim H (2017) Multivariate optimization for the simultaneous bioremoval of BTEX and chlorinated aliphatic hydrocarbons by Pseudomonas plecoglossicida. J Hazard Mater 321:238-246

Littlejohns JV, Daugulis AJ (2008) Kinetics and interactions of BTEX compounds during degradation by a bacterial consortium. Process Biochem 43:1068-1076

Liu W, Marsh T, Cheng H, Forney L (1997) Characterization of microbial diversity by determining terminal restriction fragment length polymorphisms of genes encoding 165 rRNA. Appl Environ Microbiol 63:4516-4522

Maier RM (2000) Microorganisms and organic pollutants. In: Environmental microbiology. Maier RM, Pepper IL, Gerba CP. San Diego: Academic Press, p. 63-402

Mascolo G, Ciannarella R, Balest L, Lopez A (2008) Effectiveness of UV-based advanced oxidation processes for the remediation of hydrocarbon pollution in the groundwater: a laboratory investigation. J Hazard Mater 15:1138-1145

Máthé I, Benedek T, Táncsics A, Palatinszky M, Sz L, Márialigeti K (2012) Diversity, activity, antibiotic and heavy metal resistance of bacteria from petroleum hydrocarbon contaminated soils located in Harghita County (Romania). Int Biodeterior Biodegrad 73:41-49

Mazzeo DEC, Levy CE, de Angelis DDF, Marin-Morales MA (2010) BTEX biodegradation by bacteria from effluents of petroleum refinery. Sci Total Environ 408:4334-4340

Miri S, Davoodi SM, Darvanjooghi MHK, Brar SK, Rouissi T, Martel R (2021) Precision modelling of co-metabolic biodegradation of recalcitrant aromatic hydrocarbons in conjunction with experimental data. Process Biochem. https://doi.org/10.1016/j.procbio.2021.03.026

Mitra S, Roy P (2011) BTEX: A serious ground-water contaminant. Res J Environ Sci 5:394-398

Mohan H, Lim JM, Cho M, Park YJ, Seralathan KK, Oh BT (2020) Remediation of BTEX and $\mathrm{Cr}(\mathrm{VI})$ contamination in soil using bioelectrochemical systeman eco-friendly approach. Environ Sci Pollut Res 27:837-845

Morales M, Sentchilo V, Bertelli C, Komljenovic A, Kryuchkova-Mostacci N, Bourdilloud A, Linke B, Goesmann A, Harshman K, Segers F, Delapierre F, Fiorucci D, Seppey M, Trofimenco E, Berra P, El Taher A, Loiseau C, Roggero D, Sulfiotti M, Etienne A, Ruiz Buendia G, Pillard L, Escoriza A, Moritz R, Schneider C, Alfonso E, Ben Jeddou F, Selmoni O, Resch G, Greub G, Emery O, Dubey M, Pillonel T, Robinson-Rechavi M, van der Meer JR (2016) The genome of the toluene-degrading Pseudomonas veronii strain 1 YdBTEX2 and its differential gene expression in contaminated sand. PLoS ONE. https://doi.org/10.1371/journal.pone.0165850

Mrozik A, Piotrowska-Seget Z (2010) Bioaugmentation as a strategy for cleaning up of soils contaminated with aromatic compounds. Microbiol Res 20:363-375

Nagarajan K, Loh KC (2015) Formulation of microbial cocktails for BTEX biodegradation. Biodegradation 26:51-63

Nam IH, Chang YS, Hong HB, Lee YH (2003) A novel catabolic activity of Pseudomonas veronii in biotransformation of pentachlorphenol. Appl Microbiol Biotechnol 62:284-290

Nowak A, Mrozik A (2016) Facilitation of co-metabolic transformation and degradation of monochlorophenols by Pseudomonas sp CF600 and changes 
in its fatty acid composition. Water Air Soil Pollut 227:83. https://doi.org/ 10.1007/s11270-016-2775-5

Onaca C, Kieninger M, Engesser KH (2007) Degradation of alkyl methyl ketones by Pseudomonas veronii MEK700. Am Soc Microbiol 189:3759-3767

Posman KM, DeRito CM, Madsen EL (2017) Benzene degradation by a Variovorax species within a coal tar contaminated groundwater microbial community. Appl Environ Microbiol 83:e02658-e2716

Prestes de Castro B, de Souza MG, Bauerfeldt GF, Domingos Nunes Fortes J, Monteiro Martins E (2015) Assessment of the BTEX concentrations and reactivity in a confined parking area in Rio de Janeiro, Brazil. Atm Environ 104:22-26

Rahul MAK, Balomajumder C (2013) Biological treatment and modelling aspect of BTEX abatement process in a biofilter. Bioresour Technol 142:9-17

Satola B, Wübbeler JH, Steinbüchel A (2013) Metabolic characteristics of the species Variovorax paradoxus. Appl Microbiol Biotechnol 97:541-560

Shim H, Shin E, Yang ST (2002) A continuous fibrous-bed bioreactor for BTEX biodegradation by a co-culture of Pseudomonas putida and Pseudomonas fluorescens. Adv Environ Res 7:203-216

Singh A, Ward OP (2004) Biotechnology and bioremediation an overview. In: Singh A, Ward OP (eds) Biodegradation and Bioremediation. Springer, Berlin

Singh P, Jain R, Srivastava N, Borthakur A, Pal D, Singh R, Madhav S, Srivastava P, Tiwary D, Mishra PK (2017) Current and emerging trends in bioremediation of petrochemical waste: a review. Crit Rev Environ Sci Technol 47:155-201

Smith MT, Guyton KZ, Gibbons CF, Fritz JM, Portier CJ, Rusyn I, DeMarini DM, Caldwell JC, Kavlock RJ, Lambert PF (2016) Key characteristics of carcinogens as a basis for organizing data on mechanisms of carcinogenesis. Environ Health Perspect 124:713-721

Snellinx Z, Taghavi S, Vangronsveld J, van der Lelie D (2003) Microbial consortia that degrade 2,4-DNT by interspecies metabolism: isolation and characterization. Biodegradation 14:19-29

Táncsics A, Szoboszlay S, Szabó I, Farkas M, Kovács B, Kukolya J, Mayer Z, Kriszt B (2012) Quantification of subfamily I.2.C catechol 2,3-dioxygenase mRNA transcripts in groundwater samples of an oxygen-limited BTEX-contaminated site. Environ Sci Technol 46:232-240

Vasilyeva G, Kondrashina V, Strijakova E, Ortego-Calvo JJ (2020) Adsorptive bioremediation of soil is higly contaminated with crude oil. Sci Tot Environ 706:135739

Wang L, Qiao N, Sun F, Shao Z (2008) Isolation, gene detection and solvent tolerance of benzene, toluene and xylene degrading bacteria from nearshore surface water and Pacific Ocean sediment. Extremophiles 12:335-342

Wilbur S, Bosch S (2004) Interaction profile for: Benzene, Toluene, Ethylbenzene, and Xylenes (BTEX). U.S. Department of Health and Human Services Public Health Service. Agency for Toxic Substances and Disease Registry, Atlanta

Zhang F, Shang X, Chen H, Xie G, Fu Y, Wu D, Sun W, Liu P, Zhang C, Mu Y, Zeng L, Wan M, Wang Y, Xiao H, Wang G, Chen J (2020) Significant impact of coal combustion on VOCs emissions in winter in a North China rural site. Sci Tot Environ 720:137617

\section{Publisher's Note}

Springer Nature remains neutral with regard to jurisdictional claims in published maps and institutional affiliations.

\section{Submit your manuscript to a SpringerOpen ${ }^{\circ}$ journal and benefit from:}

- Convenient online submission

- Rigorous peer review

- Open access: articles freely available online

- High visibility within the field

- Retaining the copyright to your article

Submit your next manuscript at $\boldsymbol{\nabla}$ springeropen.com 